\title{
Influence of Different Levels of Aluminum on the Development of Citrus Rootstock Swingle Citrumelo (Citrus paradisi mcf. $x$ Poncirus trifoliata Raf.) in Nutrient Solution
}

\author{
Carlos Henrique dos Santos ${ }^{1 *}$, Hélio Grassi Filho ${ }^{2}$, João Domingos Rodrigues ${ }^{3}$ and Sheila \\ Zambello de Pinho ${ }^{4}$ \\ ${ }^{I}$ Departament. of Botany, Institute of Biosciences - UNESP, Campus of Botucatu, PO Box 502, CEP 18618-000, \\ Botucatu - SP; ${ }^{2}$ Departament of Soil Sciences, School of Agronomic Sciences - UNESP, Campus of Botucatu, PO \\ Box 237, CEP 18603-970, Botucatu - SP; ${ }^{3}$ Departament of Botany, Institute of Biosciences - UNESP - Campus of \\ Botucatu - PO Box 237, CEP 18603-970, Botucatu - SP; ${ }^{4}$ Departament of Biostatistics, Institute of Biosciences - \\ UNESP - Campus of Botucatu - PO Box 502, CEP 18618-000, Botucatu - SP, Brazil
}

\begin{abstract}
This work aimed at evaluating the influence of different levels of aluminum on the physiological parameters of the citrus rootstock Swingle Citrumelo in hydroponic solution. The experiment was carried out with a completely randomized design with three replications, subdivided in several lots. The levels of aluminum used were: 0, 7.5, 15, 22.5 and $30 \mathrm{mg} \mathrm{L}^{-1}$ in form of $\mathrm{AlCl}_{3} .6 \mathrm{H}_{2} \mathrm{O}$ in nutrient solution. Following physiological parameters were evaluated: specific and relative foliar area, relative foliar mass, and the ratio of aerial part dry matter/root system dry matter. The results showed that aluminum did not influence the parameters evaluated except the specific foliar area, which decreased starting at the $7.5 \mathrm{mg} \mathrm{L}^{-1}$ level.
\end{abstract}

Key words: Citrus, rootstocks, aluminum, mineral nutrition, growth analysis.

\section{INTRODUCTION}

Brazil has vast areas favorable to cultivation of citrus, some of which consist of low fertility, acid soils, with high aluminum content (Vasconcelos, 1987 and Nogueira et al., 1989).

Research into the toxicity of aluminum to the physiology of plants has shown that this element interferes in the cellular division in roots, decreases cellular respiration of roots, interferes with certain enzymes that orient the deposit of polysaccharids on the cell walls, increases the rigidity of the cell walls due to the deposit of pectides, and interferes in absorption. According to Foy et al. (1978), the apex of the main roots thickens and turns brown. The degree of inhibition of the root system development is one of the available indicators of genotipical differences of tolerance to aluminum (Marschner, 1995). This tolerance varies between and within species, thus permitting the establishment of criteria of adaptability. However, the exact physiological mechanism of toxicity or tolerance in some species, particularly for citrus, are still being discussed (Foy et al.,1978).

The analysis of the growth rate can then be used to study the ecological adaptability of plants to different environments, the competition between species, the effects of management and practices, and the identification of productive capacity of different genotypes.

According to Magalhães (1979), the analysis of growth was defined as a method that described the morpho-physiological conditions of the plant at different intervals of time between two successive measurements in order to follow the dynamics of photosynthetic production, by measuring the accumulation of dry matter, relating to the cycle of the plant under study. Luchesi (1984) showed that with this analysis

\footnotetext{
* Author for correspondence.
} 
the effects of different treatments could be seen in detail. This type of analysis was based on the sequential measuring of organic substances at one or more phases of growth, or over the full cycle of the plant under study.

The objective of this work was to obtain information regarding the influence of aluminum on the physiological properties of citrus rootstock of Swingle citrumelo. The choice of this variety was based on the fact that the market price tendency of oranges at present is based on higher content of soluble solids in the fruit. As this variety is superior in this characteristic in relation to others, there is a strong possibility of increasing the use of this variety, in detriment to the others, in the State of São Paulo, and, possibly, in other regions (Araújo, 1995).

\section{MATERIAL AND METHODS}

Experiment was carried out in the greenhouse, with an automatic temperature control system. The average temperature and humidity data were registered througout the experiment by a thermal-higrograph fixed at 2 meters height at the center of the greenhouse, as in Table 1.

TABLE 1. Average temperatures and humidity registered during the experiment.

\begin{tabular}{cccc}
\hline Month & \multicolumn{3}{c}{ Temperature $-{ }^{\mathbf{0}} \mathbf{C}$} \\
\hline & Min. & Max. & Average \\
March & 19,5 & 37,0 & 28,3 \\
April & 16,8 & 34,8 & 25,8 \\
May & 15,9 & 30,8 & 23,4 \\
\hline Month & \multicolumn{3}{c}{ Humidity - \% } \\
\hline & Min. & Max. & Average \\
March & 91,6 & 91,6 & 80,0 \\
April & 71,6 & 93,7 & 82,7 \\
May & 86,5 & 96,4 & 91,5 \\
\hline
\end{tabular}

One hundred eighty plants of Swingle citrumelo, with approximately $10 \mathrm{~cm}$. in height, were placed in plastic trays of 141 , containing a modified solution (Furlani \& Furlani, 1988) at half the concentration and with no aluminum. The plants were held upright through the holes drilled in an isopor sheet and protected by plastic foam and remained there for 20 days for acclimatizing before replanting to minimize the effects of stress caused by the absorption of aluminum.

At the end of this period, the solution was substituted by one with adequate concentration, described in Tables 2 and 3, as well the addition of 5 levels of aluminum in the form of $\mathrm{AlCl}_{3} .6 \mathrm{H}_{2} \mathrm{O}: 0 ; 7.5 ; 15 ; 22.5$ and $30 \mathrm{mg} \mathrm{L}^{-1}$. The nutrient solution was replaced at 15 days intervals, oxygenated daily, and the $\mathrm{pH}$ of each treatment solution was also corrected at 15 days intervals to $4 \pm 0.2$ by the addition of $\mathrm{HCl} 0.1$ $\mathrm{N}$.

Table 2. Composition of the stock solution for making the nutrient solution.

\begin{tabular}{lccc}
\hline \multicolumn{1}{c}{ Elements } & Sol. Estoque & $\mathbf{g ~ L}^{-1}$ & Molar \\
\hline $\mathrm{Ca}\left(\mathrm{NO}_{3}\right)_{2} \cdot 4 \mathrm{H}_{2} \mathrm{O}$ & 1 & 472,30 & 2,00 \\
$\mathrm{NH}_{4} \mathrm{NO}_{3}$ & & 59,23 & 0,74 \\
& & & \\
$\mathrm{KNO}_{3}$ & 2 & 48,23 & 0,48 \\
$\mathrm{KCl}$ & & 37,28 & 0,50 \\
$\mathrm{~K}_{2} \mathrm{SO}_{4}$ & & 87,14 & 0,50 \\
& & & \\
$\mathrm{Mg}\left(\mathrm{NO}_{3}\right)_{2} \cdot 6 \mathrm{H}_{2} \mathrm{O}$ & 3 & 128,22 & 0,50 \\
& & & \\
$\mathrm{KH}_{2} \mathrm{PO}_{4}$ & 4 & 13,61 & 0,10 \\
& & & \\
$\mathrm{AlCl}_{3} \cdot 6 \mathrm{H}_{2} \mathrm{O}$ & 5 & 268,26 & 1,10 \\
& & & \\
$\mathrm{Fe}_{-} \mathrm{EDTA}$ & 6 & & \\
$\mathrm{MnSO}_{4} \cdot 1 \mathrm{H}_{2} \mathrm{O}$ & & & \\
$\mathrm{H}_{3} \mathrm{BO}_{3}$ & & 2,00 & \\
$\mathrm{ZnSO}_{4} \cdot 7 \mathrm{H}_{2} \mathrm{O}$ & & 2,95 & \\
$\mathrm{CuSO}_{4} \cdot 5 \mathrm{H}_{2} \mathrm{O}$ & & 0,25 & \\
$\mathrm{Na}_{2} \mathrm{MoO}_{2} \cdot 2 \mathrm{H}_{2} \mathrm{O}$ & & 0,15 & \\
\hline
\end{tabular}

Table 3. Composition of the nutrient solution in according to Furlani \&Furlani (1988).

\begin{tabular}{lccccc}
\hline \multicolumn{5}{c}{ Elem. } & \multicolumn{5}{c}{ Concentration - $\mathbf{~ m g ~ L ~}^{-1}$} \\
\hline Al & 0 & 7,5 & 15,0 & 22,5 & 30,0 \\
$\mathbf{N}_{\mathbf{N O}} \mathbf{N}_{3}$ & 147,9 & 147,9 & 147,9 & 147,9 & 147,9 \\
$\mathbf{N}-\mathbf{N H}_{\mathbf{4}}$ & 18,0 & 18,0 & 18,0 & 18,0 & 18,0 \\
$\mathbf{P}$ & 1,0 & 1,0 & 1,0 & 1,0 & 1,0 \\
$\mathbf{K}$ & 86,1 & 86,1 & 86,1 & 86,1 & 86,1 \\
$\mathbf{C a}$ & 140,0 & 140,0 & 140,0 & 140,0 & 140,0 \\
$\mathbf{M g}$ & 21,0 & 21,0 & 21,0 & 21,0 & 21,0 \\
$\mathbf{S}$ & 17,6 & 17,6 & 17,6 & 17,6 & 17,6 \\
$\mathbf{F e}$ & 5,0 & 5,0 & 5,0 & 5,0 & 5,0 \\
$\mathbf{B}$ & 0,5 & 0,5 & 0,5 & 0,5 & 0,5 \\
$\mathbf{C u}$ & 0,02 & 0,02 & 0,02 & 0,02 & 0,02 \\
$\mathbf{M n}$ & 0,5 & 0,5 & 0,5 & 0,5 & 0,5 \\
$\mathbf{Z n}$ & 0,05 & 0,05 & 0,05 & 0,05 & 0,05 \\
$\mathbf{M o}$ & 0,001 & 0,001 & 0,001 & 0,001 & 0,001
\end{tabular}


Cl

$\begin{array}{lllll}19,5 & 19,5 & 19,5 & 19,5 & 19,5\end{array}$

A completely randomized statistical method was performed with three replications, for five concentrations of aluminum, subdivided in lots of 12 plants each. The collection of each lot was done at 14 days intervals (Luchesi, 1984): 1st. 14 days, 2 nd. - 28 days, 3 rd. -42 days, 4 th. -56 days, 5th. - 70 days, 6th. - 84 days after transplanting to the nutritive solution.

Two weeks after the adaptation period, two plants of each replication within each tratament were collected and obtained their foliar area, stem and roots dry matter, in according with metodology described by Santos (1998). After was determined the physiological parameters for specific and relative foliar area, relative foliar mass, and the ratio of aerial part dry matter/root system dry matter:

Specific Foliar Area: The specific foliar area is the morphological and anatomical component of SFA, because it relates the foliar surface (FA) with the foliar dry matter (FDM). The surface is an anatomical component because it is related to the foliar intern composition (number or size of the cells of the leaf) (Benincasa, 1988).

$$
S F A=F A / F D M, \text { in } \mathrm{cm}^{2} \mathrm{~g}^{-}{ }^{1}
$$

Relative Foliar Area (RFA): It represents the foliar area effective in the photosynthesis, because it evaluates the total plant development, being determined in each one of the samples. It is considered as the quotient among the foliar surface (FA) and the mass of the dry matter total (TDM) (Luchesi, 1984).

$$
R F A=F A / T D M, \text { in } \mathrm{cm}^{2} \mathrm{~g}^{-1}
$$

Relative Foliar Mass (RFM): It is the quotient among the mass of foliar dry matter (FDM) and the mass of the total dry matter (TDM), and evaluates the ratio source-sink, wich expresses the amount of material exported by the leaf (Luchesi, 1984).

$$
R F M=F D M / T D M, \text { in } g g_{-}{ }^{1}
$$

Ratio Aerial Parts Dry Matter / Root System Dry Matter (APDM/RSDM): This parameter allows to analyze the growth of the aerial part in relation to the growth of the root system. It is obtained through the equation (Luchesi, 1984): $A P D M / R S D M=(S D M+L D M) / R S D M$, in $g g^{-1}$

Then: SDM = Stem Dry Matter

LDM = Leaves Dry Matter

RSDM = Root System Dry Matter

\section{RESULTS AND DISCUSSION}

The plants examined at each stage showed significant development of foliar area in function of time and stablization of dry matter till the final measurements, thereby increasing the value of the specific foliar area (SFA) (Figure 1).

The larger concentrations of aluminum remained in the roots (Tables 4 and 5), and although the aluminum found in the leaves interfered with the concentration and effectiveness of the calcium in the foliar development, as showed by Clarkson \& Anderson (1969), Taylor (1988), Akeson et al. (1989), and Haug \& Shi (1991), but this interference was not drastic. The genetically conditioned foliar expansion was larger than the accumulation of dry matter in the leaves, leaving these with less reserves, and therefore less thickness, as the plant developed. According to Benincasa (1988), the specific foliar area (SFA) is in inverse ratio to leaf thickness, as the morphological and anatomical behavior of the relative foliar area (RFA) will relate the surface area with the weight dry matter of the leaf. Therefore, it seems that at the start of development, the values of SFA will be greater, indicating thinner leaves with little dry matter and small surface area. Therefore, it is evident that as development occurs with increasing leaf area, accumulation of dry matter in these leaves will also occur, and since the SFA links surface area with weight, there will be a tendency to decrease the values of this parameter shortly after the first collection, to then stabilize for the succeeding collections (Rodrigues, 1990). However, according to Pereira \& Machado (1987), with some crops, the values of the SFA could remain steady, or vary insignificantly during the plant growth period. This behavior is characteristic of annual plant crops, unlike 
perennial plant crops. Regarding the physiological parameters, Swingle citrumelo presented similar behavior in all the treatments.

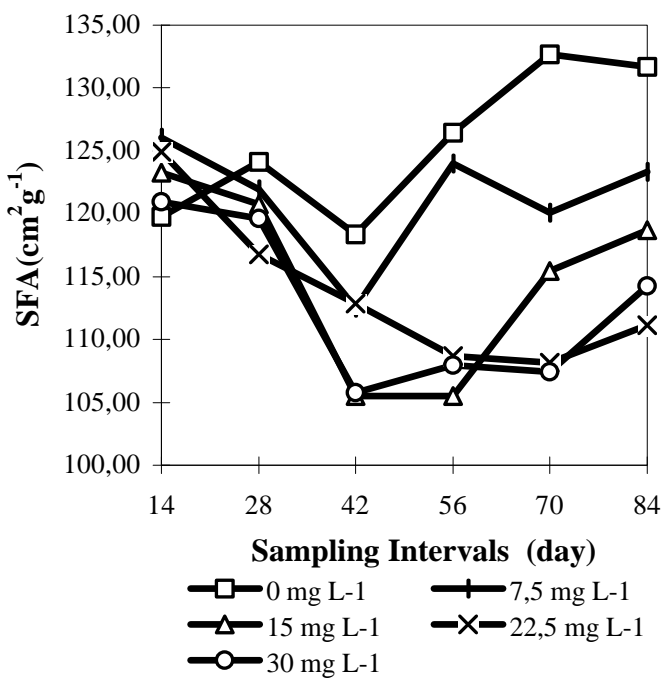

Figure 1. Average values of Specific Foliar Area of Swingle citrumelo under hydroponic conditions at different levels of $\mathrm{Al}$.

Table 4. Average results of accumulation of $\mathrm{Al}(\mu \mathrm{g})$ in the aerial part and roots of Swingle citrumelo under different levels of $\mathrm{Al}$ in nutrient solution.

\begin{tabular}{lcc}
\hline \multirow{2}{*}{$\begin{array}{l}\text { Treatments } \\
\text { mg L }^{-1}\end{array}$} & \multicolumn{2}{c}{ Swingle Citrumelo } \\
\cline { 2 - 3 } 0 & Aerial Parts & Roots \\
\hline 7,5 & $155,38 \mathrm{~A}$ & $310,79 \mathrm{~B}$ \\
15 & $124,80 \mathrm{~A}$ & $743,28 \mathrm{~A}$ \\
22,5 & $132,01 \mathrm{~A}$ & $767,27 \mathrm{~A}$ \\
30 & $133,84 \mathrm{~A}$ & $898,82 \mathrm{~A}$ \\
\hline Test F & $138,54 \mathrm{~A}$ & $832,65 \mathrm{~A}$ \\
CV $(\%)$ & NS & $* *$ \\
\hline Aver & 38,48 & 34,59 \\
\hline
\end{tabular}

Averages followed by the same letter, in the columns, didn't differ to each other for the Tukey's test at the level of $5 \%$.

Table 5. Average results of accumulation of $\mathrm{Al}(\mu \mathrm{g})$ in the aerial part and roots under of Swingle Citrumelo different levels of $\mathrm{Al}$ and collection in nutrient solution.

\begin{tabular}{lcc}
\hline Sampling & \multicolumn{2}{c}{ Swingle Citrumelo } \\
\cline { 2 - 3 } Intervals & Aerial Part & Roots \\
\hline $1^{\mathrm{a}}$ coleta & $67,44 \mathrm{C}$ & $397,63 \mathrm{C}$ \\
$2^{\mathrm{a}}$ coleta & $113,88 \mathrm{~B}$ & $656,09 \mathrm{~B}$ \\
$3^{\mathrm{a}}$ coleta & $114,35 \mathrm{~B}$ & $657,99 \mathrm{~B}$ \\
$4^{\mathrm{a}}$ coleta & $140,59 \mathrm{~B}$ & $628,53 \mathrm{~B}$ \\
$5^{\mathrm{a}}$ coleta & $184,61 \mathrm{~A}$ & $904,09 \mathrm{~A}$ \\
$6^{\mathrm{a}}$ coleta & $200,63 \mathrm{~A}$ & $1019,04 \mathrm{~A}$ \\
\hline Test $\mathrm{F}$ & $* *$ & $* *$ \\
$\mathrm{CV}(\%)$ & 25,21 & 18,16 \\
\hline
\end{tabular}

Averages followed by the same letter, in the columns, didn't differ to each other for the Tukey's test at the level of $5 \%$.

The results showed that the Swingle citrumelo plants presented decreasing values for RFA with age for all levels of aluminum studied (Figure 2).

On the other hand, there was an increase of total dry matter weight (TDM), with a decreased of RFA. It is similar to the report of Aguiar Netto (1997) with potato crop, where the RFA decreases with the growth of the plants, indicating differential partition of assimilated elements, because while total dry matter tended to increase, foliar area tended to decrease. Was more easily visualized with short cycle crops than with citric rootstock, which was of slow development. According to Rodrigues (1982) this parameter represented the relative dimension of the photosynthetic system, being appropriate to the evaluation of the effects of genotype selection, climate, and management of the vegetation. This physiological index also showed the useful leaf area for photosynthesis, as it is part of the morphological behavior for measuring growth rates (Benincasa, 1988). The control plants presented similar values probably due to a fungus disease that appeared in the root system, chiefly in the lower level aluminum treatments. This was immediately treated and eliminated.

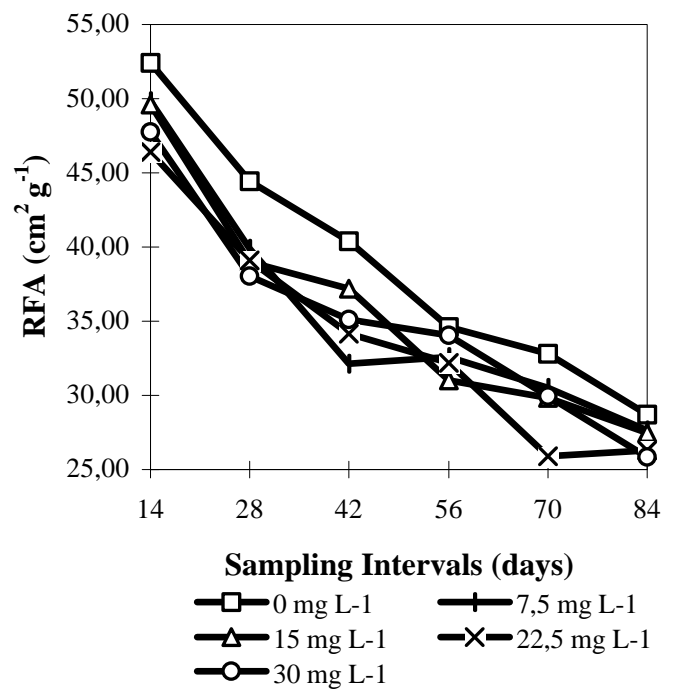

Figure 2. Average readings of Relative Foliar Area of Swingle citrumelo in hydroponic conditions, at different levels of aluminum. 
As with leaf area, the plants maintained their foliar dry matter weight practically constant throughout the experiment, but with the plant growth the total dry matter (TDM) increased, consequently the relative foliar mass (RMF) decreased (Figure 3). Thus the general tendency was toward a decrease of the RMF during the growth of Swingle citrumelo in all treatments as was found by Rodrigues (1982) with soybean crop, Rodrigues (1990) with Stylozanthes guianensis, and Aguiar Netto (1997) with potato crop.

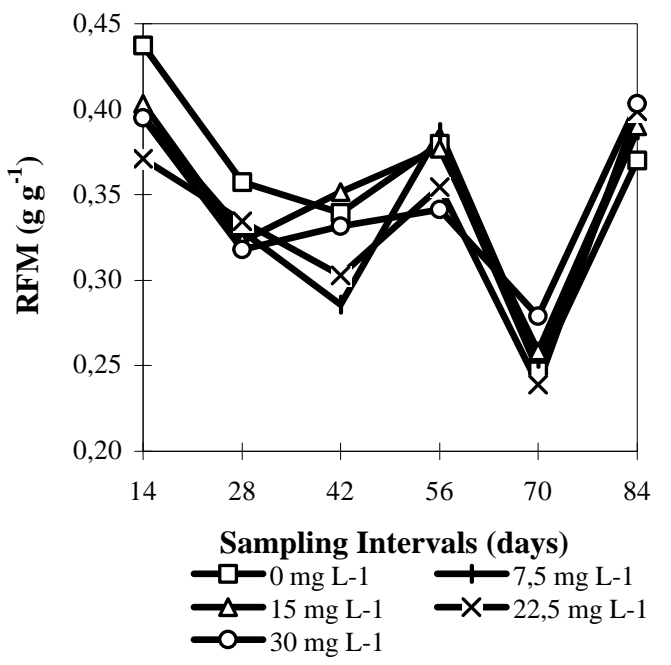

Figure 3. Average readings of the Relative Foliar Mass in Swingle citrumelo, under hydroponic conditions, at different levels of aluminum.

The ratio of aerial part dry matter (APDM) to root dry matter (RDM) in Swingle citrumelo (Figure 4) showed that even with the stable accumulation of dry matter in the leaves, there was a higher accumulation of organics substances in the root system, according to the readings of the values dry matter weight at the final phase of the experiment, thus reducing the ratio. In coffee, Pavan \& Bingham (1982) reported a decrease in the ratio aerial part/roots with the addition of aluminum of to the nutrient solution. The authors concluded, that a high ratio suggested that the root system was efficient in the absorption of water and nutrients and was able to support the aerial parts development.
This ratio indicated at various stages of growth of the plants, the organs wich accumulation higher organic substance, provoking more growth (Rodrigues, 1982). The analysis of this ratio showed that the ratio of aerial/roots was correlated development, indicating that the growth of root could affect the aerial part and vice-versa (Rodrigues, 1990). Any factor affecting growth of roots or aerial part, altering this ratio, would in turn affect productivity, particularly regarding the aerial part, of which the growth may occur in detriment of the roots.

As there was similar behavior in all the treatments under similar conditions, it is inferred that aluminum did not influence the ratios discussed above, except for the SFA, wich decreased at levels higher $7,5 \mathrm{mg} \mathrm{L}^{-1}$ of aluminum.

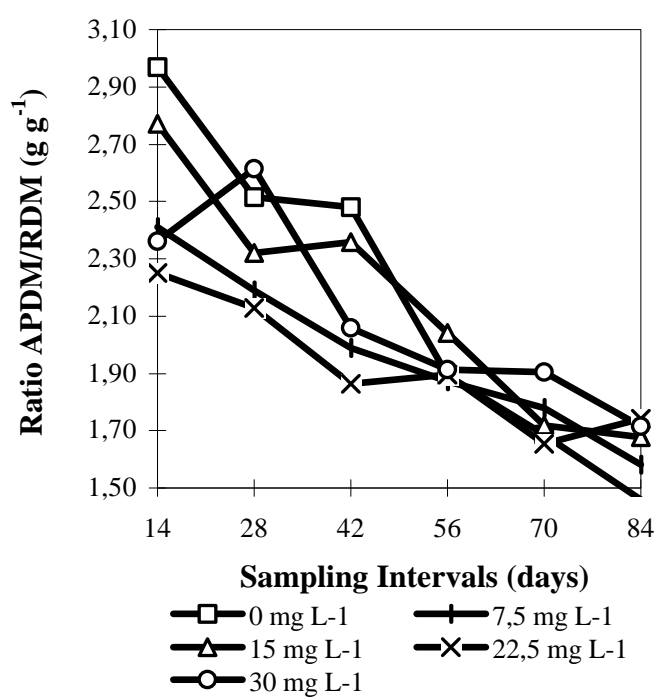

Figure 4. Average readings of the ratio ADM/RDM in Swingle citrumelo, under hydroponic conditions, at different levels of aluminum.

\section{ACKNOWLEDGEMENTS}

The authors are grateful to CAPES for financial aid for post-graduate study.

\section{RESUMO}

O presente trabalho teve como objetivo avaliar a influência de diferentes níveis de alumínio nos 
parâmetros fisiológicos do porta-enxerto cítrico citrumeleiro Swingle em cultivo hidropônico. $\mathrm{O}$ experimento foi conduzido seguindo $\mathrm{O}$ delineamento estatístico inteiramente casualizado, com 3 repetições, em parcelas subdivididas. Os níveis de alumínio utilizados foram: $0,7,5,15,22,5$ e $30 \mathrm{mg} \mathrm{L}^{-1}$, na forma de $\mathrm{AlCl}_{3} \quad 6 . \mathrm{H}_{2} \mathrm{O}$ em solução nutritiva. Foram avaliados os parâmetros fisiológicos área foliar específica, razão de área foliar e massa foliar, relação matéria seca da parte aérea/matéria seca do sistema radicular. De acordo com os resultados obtidos nestas condições, conclui-se que os níveis de alumínio não influenciaram nos valores dos parâmetros acima discutidos, excetuando-se a AFE, havendo decréscimos destes valores a partir de 7,5 $\mathrm{mg} \mathrm{L}^{-1}$ de alumínio.

\section{REFERENCES}

Aguiar Netto, A.O. (1997), Crescimento $e$ produtividade da cultura da batata (Solanum Tuberosum ssp tuberosum) cultivar Aracy, submetida a diferentes lâminas de irrigação. Tese de Doutorado, Faculdade de Ciências Agronômicas, Universidade Estadual Paulista, Botucatu, Brasil.

Araújo, J.R.G. (1995), Desenvolvimento $e$ concentração mineral em três variedadescopa de citrus (Citrus spp), sob influência de diferentes porta-enxertos. Dissertação de Mestrado, Faculdade de Ciências Agronômicas, Universidade Estadual Paulista, Botucatu, Brasil.

Akeson, M., Munns, D., Burau, R.G. (1989), Adsorption of $\mathrm{Al}^{3+}$ to phosphatidyl choline vesicles. Acta Biochim. Biophys., 986, 3340.

Benincasa, M.M.P. (1988), Análise de crescimento de plantas. UNESP, Jaboticabal, pp. 42.

Clarkson, D.T., Sanderson, J. (1969), The uptake of a polyvalent cation and its distribution in the root apices of Allium cepa. Tracer and auto radio graphic studies. Planta, 89, 136-154.

Foy, C.D., Chaney, R.L., White, M.C. (1978), The physiology of metal toxicity in plants. Annu. Rev. Plant Physiol., 29, 511-566.
Furlani, A.M.C., Furlani, P.R. (1988), Composição e $\mathrm{pH}$ de soluções nutritivas para estudos fisiológicos e seleção de plantas em condições adversas. Bol. Téc. Inst. Agron., Campinas, 121, 21-26.

Haug, A., Shi, B. (1991), Biochemical basis of aluminium tolerance in plant cells. In - Plant soil interactions at low $\mathrm{pH}$, eds. Wright, R.J., Baligar, V.C., Murmman, R.P. Dordrecht, Kluwer, pp. 839-850.

Luchesi, A.A. (1984), Utilização prática da análise de crescimento vegetal.. An. Esc. Super. Agric. Luiz de Queiroz, 41, 181-202.

Magalhães, A.C.N. (1979), Análise quantitativa de crescimento. In - Fisiologia vegetal,coord. Ferri, M.G. EDUSP, São Paulo, pp. 331-350.

Marschner, H. (1995), Mineral nutrition of higher plants. 2 ed. Academic Press, pp. 889.

Nogueira, S.S., Nagai, V., Carelli, M.L.C., Fahl, J.J. (1989), Comportamento de portaenxertos de citros em presença de alumínio. Pesqui. Agropecu. Bras., 24, 6, 711-716.

Pavan, M.A., Bingham, F.T. (1982), Toxidez de alumínio em cafeeiros cultivados em solução nutritiva. Pesqui. Agropecu. Bras., 17, 9, 1293-1302.

Pereira, A.R, Machado, E.C. (1987), Análise quantitativa do crescimento de comunidades vegetais. Bol. do Inst. Agron., Campinas, 14, 1-33.

Rodrigues, J.D. (1990), Influência de diferentes níveis de cálcio, sobre o desenvolvimento de plantas de estilosantes (Stylosanthes guyanensis (Aubl.) Swartz cv. Cook), em cultivo hidropônico. Tese de Livre Docência, Instituto de Biociências, Universidade Estadual Paulista, Botucatu, Brasil

Rodrigues, S.D. (1982), Análise de crescimento de plantas de soja (Glycine max (L.) Merrill) submetidas à carências nutricionais. Dissertação de Mestrado, Instituto de Biociências, Universidade Estadual Paulista, Rio Claro, Brasil.

Santos, C.H. (1998), Influência de diferentes níveis de alumínio no desenvolvimento de dois porta-enxertos cítricos em cultivo hidropônico. Botucatu, 1998. 134 p. Dissertação (Mestrado em Agronomia/Horticultura) - Faculdade de 
Ciências Agronômicas, Universidade Estadual Paulista.

Taylor, G.I. (1988), The physiology of aluminum phytotoxicity. In - Metal ions in biological systems,eds. Sigel, H., Sigel, A. Marcel Dekker, New York:, 24, pp. 123-163.

Vasconcellos, L.A.B.C. (1987), Comportamento de porta-enxertos de citros (Citrus spp) em três tipos de solos com diferentes níveis de alumínio e manganês. Tese de Doutorado, Escola Superior de Agricultura Luiz de Queiroz, Universidade de São Paulo, Piracicaba, Brasil.
Received: November 17, 1998 ; Revised: March 29, 1999; Accepted: August 25, 1999. 